San Jose State University

SJSU ScholarWorks

Master's Theses

Master's Theses and Graduate Research

1992

\title{
Spontaneous mutation in Escherichia coli under aerobic and anaerobic conditions
}

Parivash Hashemi

San Jose State University

Follow this and additional works at: https://scholarworks.sjsu.edu/etd_theses

\section{Recommended Citation}

Hashemi, Parivash, "Spontaneous mutation in Escherichia coli under aerobic and anaerobic conditions"

(1992). Master's Theses. 466.

DOI: https://doi.org/10.31979/etd.4c8u-wsvg

https://scholarworks.sjsu.edu/etd_theses/466

This Thesis is brought to you for free and open access by the Master's Theses and Graduate Research at SJSU ScholarWorks. It has been accepted for inclusion in Master's Theses by an authorized administrator of SJSU

ScholarWorks. For more information, please contact scholarworks@sjsu.edu. 


\section{INFORMATION TO USERS}

This manuscript has been reproduced from the microfilm master. UMI films the text directly from the original or copy submitted. Thus, some thesis and dissertation copies are in typewriter face, while others may be from any type of computer printer.

The quality of this reproduction is dependent upon the quality of the copy submitted. Broken or indistinct print, colored or poor quality illustrations and photographs, print bleedthrough, substandard margins, and improper alignment can adversely affect reproduction.

In the unlikely event that the author did not send UMI a complete manuscript and there are missing pages, these will be noted. Also, if unauthorized copyright material had to be removed, a note will indicate the deletion.

Oversize materials (e.g., maps, drawings, charts) are reproduced by sectioning the original, beginning at the upper left-hand corner and continuing from left to right in equal sections with small overlaps. Each original is also photographed in one exposure and is included in reduced form at the back of the book.

Photographs included in the original manuscript have been reproduced xerographically in this copy. Higher quality $6^{\prime \prime} \times 9^{\prime \prime}$ black and white photographic prints are available for any photographs or illustrations appearing in this copy for an additional charge. Contact UMI directly to order.

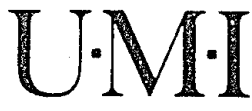

University Microlılms International

A Bell \& Howell Inlormation Company

300 North Zeeb Road. Ann Arbor. MI 48106-1346 USA

$313: 761.4700 \quad 800: 521.0600$ 
Order Number 1351037

Spontaneous mutation in Escherichia coli under aerobic and anaerobic conditions

Hashemi, Parivash, M.A.

San Jose State University, 1992 


\title{
SPONTANEOUS MUTATION IN ESCHERICHIA COLI UNDER AEROBIC AND ANAEROBIC CONDITIONS
}

\author{
A Thesis \\ Presented to \\ The Faculty of Department of Biological Sciences \\ San Jose State University
}

In partial Fulfillment

of the Requirements for the Degree

Masters of Arts

By

Parivash Hashemi

December, 1992 
APPROVED FOR THE DEPARTMENT OF BIOLOGICAL SCIENCES

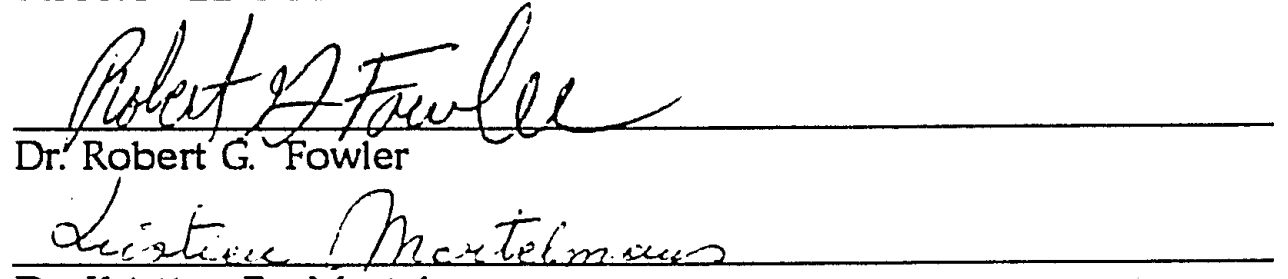
Dr. Kristien E. Mortelmans

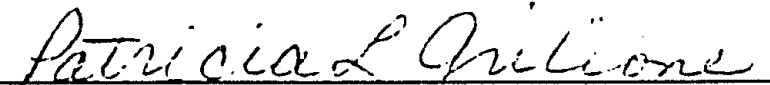

Dr. Patricia L Grilione

APPROVED FOR THE UNIVERSITY

Serena H. Ltanfore 
To My Loving Parents: Parichehreh and Mahmoud Hashemi 


\section{ACKNOEWLEDGMENTS}

I wish to express my appreciation to Dr. Fowler for his contributions to the development of this research and to Dr. Grillion for her guidance in finalizing it. I give special thanks to Dr. Mortelmans for her guidance. With her support I found the strength to work with the anaerobic chamber. Yet, without question, the most support came from Parichehr and Mahmoud Hashemi, my loving parents. 


\section{Table of Contents}

PAGE

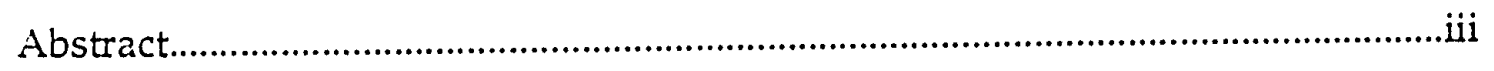

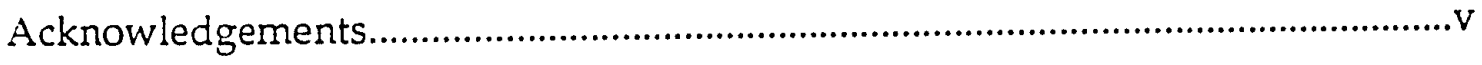

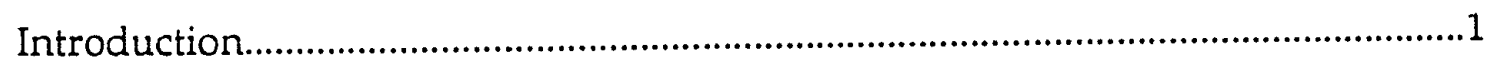

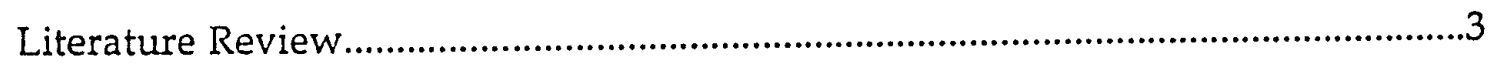

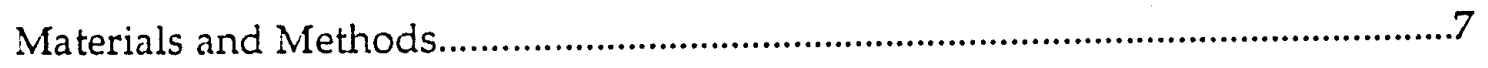

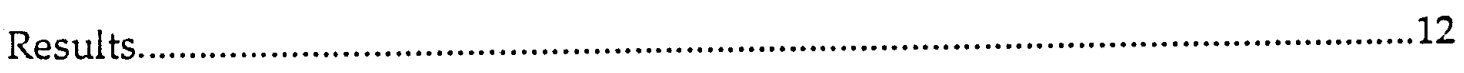

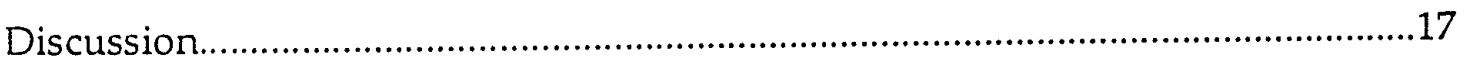

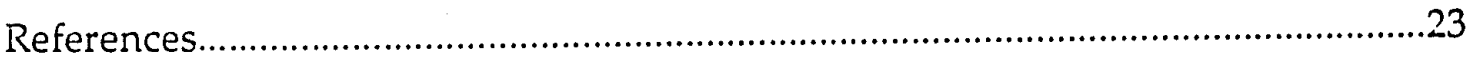




\section{List of Tables}

PAGE

1. Mutation frequencies of $\operatorname{trp} A$ strains in aerobic and anaerobic

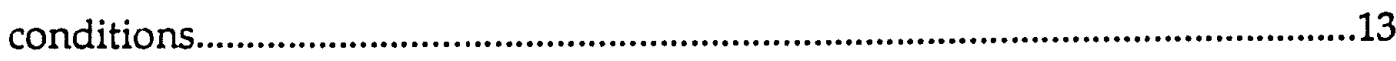

2. $\operatorname{Trp}^{+}$reversion frequencies of $\operatorname{trp} A$ strain in aerobic and anaerobic

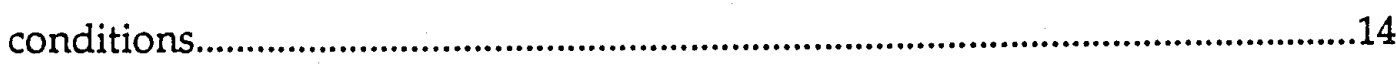

3. Characterization and distribution of revertants of $\operatorname{trp} A$ base-pair substitution mutations recovered in the presence and absence of

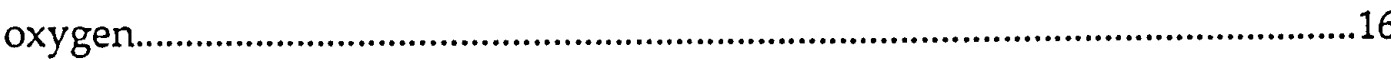




\section{ABSTRACT \\ SPONTANEOUS MUTATION IN ESCHERICHIA COLI UNDER AEROBIC AND ANAEROBIC CONDITIONS}

by Parivash Hashemi

Spontaneous mutation and reversion frequencies for $E$. coli strains carrying trpA alleles ( $A 23, A 46$ and $A 58$ ) were measured under aerobic and anaerobic conditions. The anaerobic chamber used in this experiment did not allow oxygen concentration above $0.1 \%$. In general nalidixic acid resistance $(\mathrm{Nal} R$ ) and rifampicin resistance ( $\mathrm{Rif} R$ ) mutation frequencies were two to three-fold higher under aerobic conditions than in an anaerobic environment. Likewise $\mathrm{Trp}^{+}$reversion frequencies were also two to threefold higher aerobically than anaerobically. In the limited number of trpA sites characterized, transversion base-pair substitution mutations appeared to be more severely reduced in frequency under anaerobic conditions than transitions. 


\section{Introduction}

Escherichia coli has evolved several metabolic systems for energy generation and a genetic regulatory system that selects the most efficient system in a particular environment. E. coli under natural conditions grows well aerobically as well as under low partial pressures of oxygen, for example, in the animal gut. During aerobic growth oxygen serves as terminal electron acceptor for a respiratory chain that provides both hydrogen and energy. In the absence of oxygen, anaerobic respiration occurs if an alternate electron acceptor is available such as nitrate or nitrite. In the absence of oxygen and other respiratory electron acceptors, E. coli carries out a mixed-acid fermentation where pyruvate undergoes stepwise reduction to a variety of end products and ATP is produced exclusively by substrate-level phosphorylations.

Oxidative stress is the phenomenon that occurs where there is an excess of prooxidants in the cell. These oxidants, including superoxide radical $\left(\mathrm{O}_{2}^{-}\right)$, hydrogen peroxide $\left(\mathrm{H}_{2} \mathrm{O}_{2}\right)$, and hydroxyl radicals $\left(\mathrm{OH}^{-}\right)$can be generated by the incomplete reduction of oxygen to water during respiration, by exposure to radiations, light, metals or oxidation-reduction (redox) active drugs such as paraquat, plumbagin and menadione (Stroz et al., 1990). Aerobically growing $E$. coli cells are equipped with superoxide dismutases, catalases and a variety of DNA repair enzymes which can defend against oxidative stress.

Oxygen radicals cause a great deal of damage to macromolecules in vitro and in vivo. Treatment with redox-active drugs cause both DNA and membrane damage, either of which can be lethal. Oxidant damage to DNA 
that is not repaired is thought to contribute to aging, cancer and mutagenesis. Oxygen radicals also damage RNA and proteins in vivo but this damage apparently does not cause cell death.

A major problem in studying the biological effects of oxygen radicals is the difficulty in achieving anaerobic conditions for control experiments. Several investigations have used the GasPack system for the isolation and study of anaerobic microorganisms. However, the GasPack system does not allow inspection of cultures before 48 hours (Dowell, 1972) and is often not strictly anaerobic. Anaerobic chambers with built-in incubators allow the maintenance of anaerobic conditions at all stages of culturing anaerobic microorganisms and have provided a major improvement in methodology.

The purpose of this study is to test the possibility of oxygen involvement in spontaneous mutagenesis by measuring mutation and reversion frequencies under aerobic and anaerobic conditions in genetically well-characterized E. coli strains. 


\section{Literature Review}

Over a century ago Louis Pasteur discovered that air had an inhibitory effect on bacteria that were used in the butyric fermentation process. Thus he became the first to recognize the existence of forms of life that can live only in the absence of molecular oxygen, a gas previously considered essential for the survival of all life. He introduced the terms "aerobic" and "anaerobic" to designate life in the presence of and absence of molecular oxygen, respectively.

E. coli can grow under either aerobic or anaerobic conditions. The chosen process depends on the availability of oxygen or other electron acceptors (Spiro et al., 1991). Respiration which is the translocation of electrons can occur by reduction of oxygen (aerobic respiration) or other electron acceptors such as nitrate, nitrite, fumarate, and dimethylsulphoxide (anaerobic respiration) (Poole et al., 1987; Lin et al., 1987). Molecular oxygen can not be oxidized by another molecule since a pair of electrons would antiparallel the spins of the orbit of oxygen. As a consequence of the spin restriction, molecular oxygen is not reactive with most compounds except radicals. Oxygen can increase its reactivity upon acceptance of one, two, or three electrons to form, respectively, a superoxide radical $\left(\mathrm{O}_{2}^{-}\right)$, hydrogen peroxide $\left(\mathrm{H}_{2} \mathrm{O}_{2}\right)$, and hydroxyl radicals $\left(\mathrm{OH}^{*}\right)$ or when it undergoes a spin flip to become singlet oxygen $\left(\Sigma_{\mathrm{g}} \mathrm{O}_{2}\right)$ (Foote, 1982; Hill et al., 1978). Under more acidic conditions, $\mathrm{O}_{2}$ can be protonated to form a hydoproperoxyl radical (HOO') (Bielski, 1985).

Free radicals of oxygen generated during normal metabolism are considered to be a potentially important class of endogenous mutagens 
(Harman, 1962; Totter, 1980; Ame, 1982, 1983) and, in fact, may be a critical factor in limiting the lifespan of higher animals including man (Herman, 1962; Pryor, 1982; Cutler, 1984). These radicals can have multiple effects, for example, affecting both membrane permeability and cation balance (Bennett et al., 1967). Oxygen toxicity results when the concentration of free radicals exceeds the capacity of the cell defense systems (Fridovich, 1977). Oxygen toxicity may cause several diseases such as rheumatoid arthritis, inflammatory bowel disorders, and atherosclerosis (Halliwell, 1987; Halliwell and Gutleridge, 1990). It may be one of the most important causative agents of mutagensis, tumorigenesis, and aging (Adelman et al., 1989; Ames, 1983; Amstad et al., 1990; Cerutti, 1985; Floyd, 1990).

One area of biology that is currently approaching a peak of interest is the role of oxygen metabolism in mutagenesis and carcinogenesis (Totter, 1980; Breimer, 1990; Simic et al., 1989). Treatment with oxygen at high pressures has led to increased mutation frequencies in various plant species (Berg et al., 1965), as well as modest increases in bacterial mutagenesis (Fenn et al., 1957; Gifford, 1968; Yost and Fridovich, 1967). High partial pressures of oxygen at atmospheric pressure increase chromosomal aberrations in Tradescantia microspores and dry pollen grains (Conger and Fairchild, 1952) and in Chinese-hamster lung fibroblasts (Sturrock and Nunn, 1978). An increase in mutation frequency to 8-azaguanine resistance in fibroblasts after prolonged exposure to 60-90\% oxygen (Sturrock and Nunn, 1978) and a slight increase in mutation frequency of Salmonella typhimurium strain TA 100 (but not in strain TA 1535) after treatment with 40-100\% oxygen (Kelly and Baden, 1980) have been observed. 
The above study measured the effect of increased oxygen concentrations on the Ames tester strain S. typhimurium TA 100, ( $\Delta$ uvrB pKM101) on hisG46 reversion frequencies (Kelly and Baden, 1980). These authors found a small concentration-dependet increase in mutagensis that reached a maximum ( $~ 35 \%$ increase) at $80 \%$ oxygen (air is about $20 \%$ oxygen). In another study, an increase in aeration rate of a species culture from 0.1 to 1.0 liters of air per minute increased the spontaneous mutation rate about 2fold (Sava, 1982).

When a $S$. typhimurium $\Delta$ gal-uvrB strain was grown under anoxic conditions ( $0.1 \%$ oxygen or less) 30\% fewer small deletions (3- and 6-base pair) and a five-fold decrease in minus frameshift mutations were observed. In contrast, the frequency of $\mathrm{G}: \mathrm{C} \rightarrow \mathrm{A}: \mathrm{T}$ transition mutations increased about five-fold (Hartman et al., 1984). More recently Mortelmans and Cox (1992) have shown that under strict anaerobic conditions $\mathrm{His}^{+}$revertants colonies in S. typhimurium and $\mathrm{Trp}^{+}$revertants in E. coli do not appear on selective plates. This result has been attributed to the possible production of an inhibitor of prototrophic cell growth by the auxotrophic stationary phase cells.

An $E$. coli double mutant $(\operatorname{sod} A, \operatorname{sod} B)$, completely lacking in superoxide dismutase activity, had a 40 -fold greater spontaneous mutation rate than the wild type strain during aerobic growth. This enhanced mutagensis is $\operatorname{rec} A$-independent, but is largely dependent upon the presence of a functional exonuclease III ( $x$ th gene). This suggests that oxidative damage in DNA is enhanced in the absence of superoxide dismutase, and that exonuclease III converts this damage to mutagenic lesions (Farr et al., 1986). 
Few studies have been able to quantify a direct mutagenic effect of atmospheric oxygen because of the difficulty of measuring mutation frequencies under strict anaerobic conditions. 


\section{Materials and Methods}

\section{Bacterial strains}

The tryptophan synthetase A gene mutants used in this study were obtained from Dr. Charles Yanofsky, Stanford University. The trpA mutant alleles were transduced into strain KD 1088 thr leu $\Delta$ (ton B-trp A, B) his arg as previously described (Fowler et al., 1974).

\section{Aerobic media}

VB medium is the minimal salts medium of Vogel and Bonner (1956). Minimal plates contained minimal medium solidified with $1.5 \%$ agar and supplemented with $0.2 \%$ glucose and $1 \mu \mathrm{g} / \mathrm{ml}$ thiamine. Required amino acids were added at $50 \mu \mathrm{g} / \mathrm{ml}$ to liquid media. L-agar plates consisted of $1 \%$ tryptone (Difco Laboratories), $0.5 \%$ yeast extract (Difco) and $0.5 \% \mathrm{NaCl}$ solidified with $1.5 \%$ agar (Difco). Mutation to nalidixic acid and rifampicin resistance was measured on L-agar plates containing $50 \mu \mathrm{g} / \mathrm{ml}$ nalidixic acid and $100 \mu \mathrm{g} / \mathrm{ml}$ rifampicin respectively. The saline for dilutions and washing was $0.85 \% \mathrm{NaCl}$.

\section{Prereduced anaerobically sterilized (PRAS) media}

The prereduced media were autoclaved in a three liter steel container with a sealed cover at $121^{\circ} \mathrm{C}$ for 25 minutes. A 3/8" hose from the gas $\left(\mathrm{H}_{2}, \mathrm{~N}_{2}\right.$ and $\mathrm{CO}_{2}$ ) tank was connected to the gas inlet of the container. The gas

mixture was introduced to the container through this inlet to keep the vacuumed media anaerobic. The media were then transfered to the anaerobic 
chamber through the $3 / 8^{\prime \prime}$ hose. The media plates were poured in the chamber and kept in the chamber for one week before inoculating.

\section{Anaerobic chamber}

The anaerobic chamber (Anaerobe Systems, San Jose, CA) consists of an air-tight acrylic chamber $152.4 \mathrm{~cm} \mathrm{~L} \times 76 \mathrm{~cm} \mathrm{~W} \times 44.7 \mathrm{~cm} \mathrm{H}$ (Figure 1). The armport system permits access to the interior of the chamber which consists of three parts: a. Sleeve assembly (It has a heavy duty rubber sleeve, a plastic cuff ring and a soft rubber arm cuff; the rubber cuff is responsible for making a snug, seal around the arm while working in the chamber without gloves.), b. Armport door( The armports doors are used to seal the armports while the chamber is in active use.), and c. Foot pedals (Two foot operated valves, one for gas and the other is for vacuum, are used to make the sleeve area anaerobic before removing the armport doors to inset the arms into the chamber.). A transfer module for moving materials in and out of the chamber and an incubator kept at $37^{\circ} \mathrm{C}$ are attached to either side of the chamber. The catalyst basket consists of aluminum pellets coated with palladium which are present to remove trace amounts of oxygen. The catalyst is reactivated every 3 days by heating at $160^{\circ} \mathrm{C}$ for 2 hours. A positive pressure of ca. $7.6 \mathrm{~cm}$ of water is provided by an electronic pressure controller to maintain the gaseous environment of the chamber. Anaerobic conditions are established initially in the chamber by use of a displacement balloon to physically expel air from the chamber. Then the chamber is refilled with a gas mixture of $10 \%$ hydrogen $\left(\mathrm{H}_{2}\right), 10 \%$ carbon dioxide $\left(\mathrm{CO}_{2}\right)$ and $80 \%$ nitrogen 


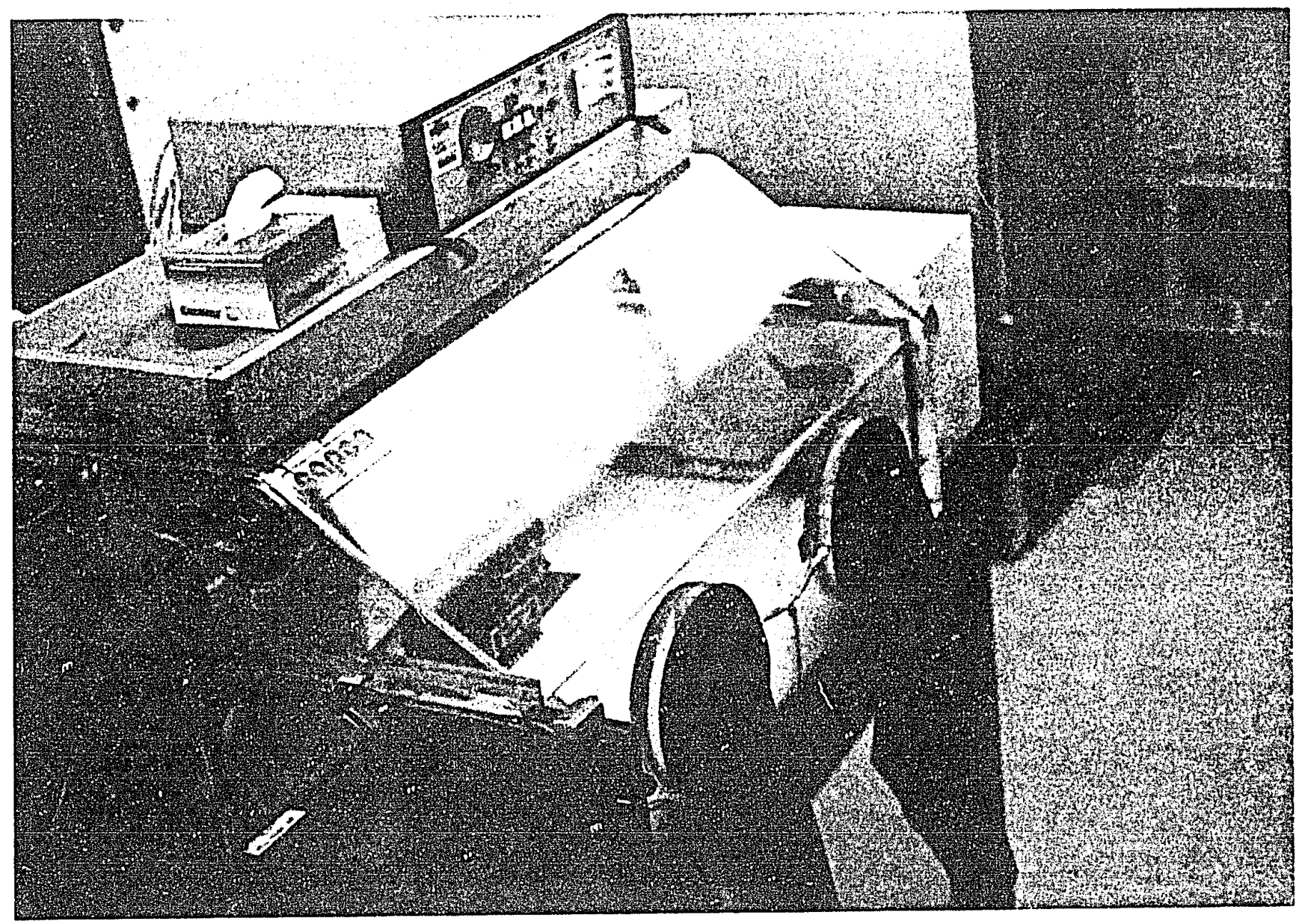

Anaerobic chamber

The arm support system with rubber sleeves are in front of chamber. The incubator is on right and passing box on left of the chamber. Control pannel is on the top of the chamber. 
(Liquid Carbonic Corp., San Carlos, CA.). This procedure is repeated twice to insure the chamber is anaerobic.

\section{Mutagenesis procedures}

For each $\operatorname{trp} A$ strain a culture was grown to saturation in the chamber (24 hours), diluted, and approximately 1000 cells were used as inocula for new cultures, one half of which were grown anaerobically in the chamber and the remaining grown aerobically. From this stage all manipulations of the anaerobic cultures were performed in the chamber (except washing by centrifugation) while the aerobic cultures were manipulated on the laboratory bench. The cultures were grown to saturation in L-broth at $37^{\circ} \mathrm{C}$ for $24 \mathrm{hrs}$. The cultures were washed in saline, diluted appropriately and plated on minimal media with tryptophan to titer for total cells and on minimal media to select for $\operatorname{Trp}^{+}$revertants. The plates were incubated at $37^{\circ} \mathrm{C}$ for $48 \mathrm{hrs}$ to titer for the total cells and for 5 days to select for Trp ${ }^{+}$revertants. Reversion frequencies for each $\operatorname{trp} A$ strain were calculated by dividing the average number of $\operatorname{Trp}^{+}$revertants by the average total cell titer. $\mathrm{Nal} R$ and $\operatorname{Rif}^{R}$ mutation frequencies were determined by plating saturated cultures on L-agar media to titer for total cells and on L-agar with $50 \mu \mathrm{g} / \mathrm{ml}$ nalidixic acid and $\mathrm{L}$ agar with $100 \mu \mathrm{g} / \mathrm{ml}$ rifampicin to select for $\mathrm{Nal}^{\mathrm{R}}$ and $\mathrm{Rif} R$ cells respectively. The plates were incubated at $37^{\circ} \mathrm{C}$ for $48 \mathrm{hrs}$. For each individual experiment two cultures of the same $\operatorname{trp} A$ strain were used, each with three selective plates and three plates for titering total cells. For each $\operatorname{trp} A$ strain the above experiment was repeated from 3 to 12 times. 


\section{Classification of $\operatorname{Trp}^{+}$revertants}

The classification of $\operatorname{Trp}^{+}$revertants of $\operatorname{trp} A$ strains was based upon two physiological tests. First, purified revertants were tested for indole glycerol phosphate (IGP) accumulation. Full revertants do not accumulate IGP; partial revertants do (Allen and Yanfsky, 1963). All Trp ${ }^{+}$revertants were tested for IGP accumulation. Second, various partial revertants can often be distinguished quantitatively by their sensitivity to 5-methyl tryptophan (5MT) (Lester and Yanofsky, 1961). Partial or suppressed revertants growing on agar plates show much larger zones of inhibition than full revertants around disks impregnated with 5-MT (Cox et al., 1972; Fowler et al., 1974). The 5- MT inhibition test was used to classify all partial revertants of $\operatorname{trp} A$ alleles 23,46 , and 58 . 


\section{Results}

\section{Effect of oxygen on mutation and reversion frequencies}

Three $\operatorname{trp} A$ strains ( $A 23, A 46$ and $A 58$ ) were examined for possible differences in mutation and reversion frequencies in the presence and absence of oxygen. Mutation frequencies to nalidixic acid $(\mathrm{Nal} R)$ and rifampicin $(\mathrm{Rif} R)$ resistance are shown in Table 1.

In the presence of oxygen, all three strains showed higher $\operatorname{Rif}^{R}$ frequencies than were found anaerobically with aerobic frequencies 2-4-fold higher than anaerobic frequencies (Table 1 ). The Nal $R$ aerobic mutation frequencies were higher than anaerobic values for the $\operatorname{trp} A 23$ and $\operatorname{trp} A 58$ strains but there was a $3-4$-fold increase in the anaerobic frequency for the $\operatorname{trp} A 46$ strain.

$\operatorname{Trp}^{+}$reversion frequencies for the $\operatorname{trp} A$ strains are shown in Table 2. Based upon revertants per $10^{8}$ cells the average frequency of $\operatorname{Trp}^{+}$revertants for $\operatorname{trp} A 23$ cells showed a 2 -fold increase aerobically as compared to the anaerobic frequency. In the presence of oxygen $\operatorname{trp} A 46$ displayed a reversion frequency which was 10 -fold higher than the anaerobic frequency. No Trp ${ }^{+}$ revertants of $\operatorname{trp} A 58$ were found under anaerobic conditions.

The number of $\mathrm{Trp}^{+}$revertants per plate in aerobic and anaerobic environments is also indicated in Table 2. The revertants per plate for $\operatorname{trp} A 23$ revealed a 1-2-fold increase aerobically as compared to anaerobic conditions. In the presence of oxygen trpA 46 has 3-4-fold higher number of revertants per plate as compared with no oxygen. 
Table 1. Mutation frequencies of $\operatorname{trp} A$ strains in aerobic and anaerobic conditions.

\begin{tabular}{|c|c|c|c|c|c|c|}
\hline \multirow{3}{*}{$\operatorname{trp} A$ allele } & \multicolumn{6}{|c|}{ Mutants per $10^{8}$ cells } \\
\hline & \multicolumn{3}{|c|}{ Nal $R$} & \multicolumn{3}{|c|}{ Rif $R$} \\
\hline & Exp & Aerobic & Anaerobic & Exp & Aerobic & Anaerobic \\
\hline \multirow[t]{9}{*}{$A 23$} & 1 & 0.67 & 0 & 1 & 1.17 & 0 \\
\hline & 2 & 0.35 & 0 & 2 & 3 & 0 \\
\hline & 3 & 1.04 & 0 & 3 & 0 & 0 \\
\hline & 4 & 2.98 & 0.64 & 4 & 4.26 & 0.08 \\
\hline & 5 & 1.17 & 0 & 5 & 2.4 & 2.64 \\
\hline & 6 & 0.79 & 0 & 6 & 2.69 & $\mathrm{ND}^{\mathrm{a}}$ \\
\hline & 7 & 2.92 & ND & 7 & 4.02 & ND \\
\hline & 8 & 0.73 & ND & 8 & 2.93 & ND \\
\hline & 9 & 0.79 & ND & 9 & 2.69 & ND \\
\hline Average & & 1.27 & 0.11 & & 2.57 & 0.54 \\
\hline \multirow[t]{12}{*}{$A 46$} & 1 & 0.09 & 0.1 & 1 & 0.27 & 0 \\
\hline & 2 & 0.17 & 0 & 2 & 7.14 & 0.13 \\
\hline & 3 & 0.64 & 5.55 & 3 & 2.49 & 1.15 \\
\hline & 4 & 0.32 & 0.76 & 4 & 0.95 & 2.65 \\
\hline & 5 & 1.84 & 3.96 & 5 & 8.51 & 3.23 \\
\hline & 6 & 0 & 0.007 & 6 & ND & 4.76 \\
\hline & 7 & 0 & 0 & 7 & ND & 0 \\
\hline & 8 & 0 & 3.23 & 8 & ND & 0 \\
\hline & 9 & 0 & 0 & 9 & ND & 4.07 \\
\hline & 10 & ND & 0 & 10 & ND & 0.27 \\
\hline & 11 & ND & 0 & 11 & ND & 0.12 \\
\hline & & & & 12 & ND & 3.9 \\
\hline Average & & 0.34 & 1.237 & & 3.87 & 1.69 \\
\hline \multirow[t]{3}{*}{$A 58$} & 1 & 0.88 & 0 & 1 & 6.57 & 3.39 \\
\hline & 2 & 0.71 & 0 & 2 & 2.27 & 1.16 \\
\hline & 3 & 2.06 & 0 & 3 & 1.43 & 0.80 \\
\hline Average & & 1.22 & 0 & & 3.42 & 1.78 \\
\hline
\end{tabular}


Table 2. $\operatorname{Trp}^{+}$reversion frequencies of $\operatorname{trp} A$ strains in aerobic and anaerobic conditions.

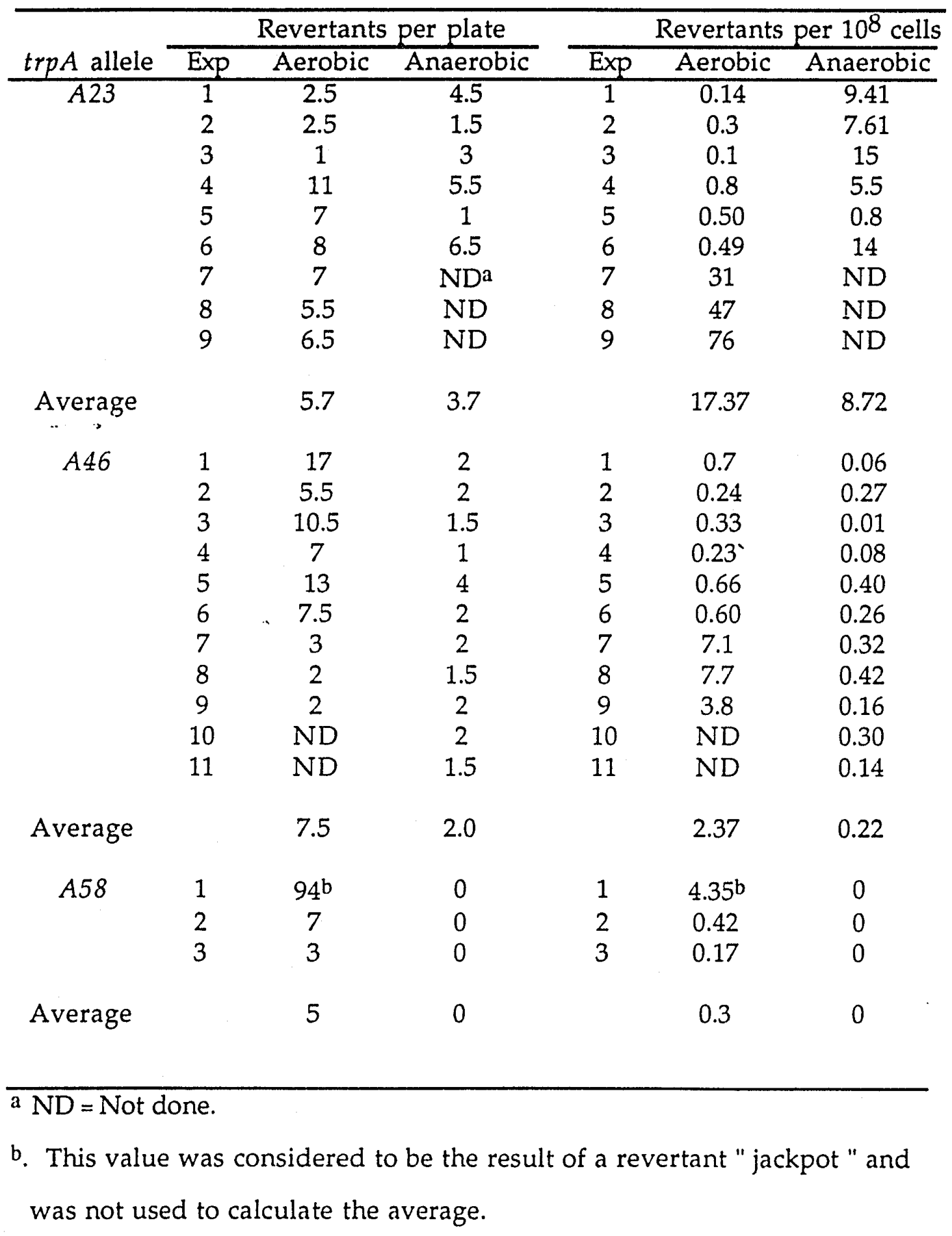




\section{Effect of oxygen on the reversion spectrum}

The specificity of aerobic and anaerobic mutagenesis was further explored by determining the reversion spectrum of the $\operatorname{trp} A$ base-pair substitutions (Yanofsky et al., 1966). Information regarding the type of reversion event occurring at the base-pair level can be obtained directly from the IGP and 5-MT phenotypes of the $\operatorname{Trp}^{+}$revertants, independent of amino acid sequence data.

The characterization and distribution of $\operatorname{Trp}^{+}$revertants of $\operatorname{trpA}$ mutants in aerobic and anaerobic conditions are presented in Table 3. Full revertants (FR I) of $\operatorname{trp} A 23$ resulted from $\mathrm{A}: \mathrm{T} \rightarrow \mathrm{G}: \mathrm{C}, \mathrm{A}: \mathrm{T} \rightarrow \mathrm{C}: \mathrm{G}$ or A:T $\rightarrow$ T:A base-pair substitutions (Yanofsky et al., 1966). In the absence of oxygen, the proportion of full revertants is enhanced as compared with the presence of oxygen (Table 3). A class of partial revertants of $\operatorname{trp} A 23$ (III PR) resulting from $\mathrm{C}: \mathrm{G} \rightarrow \mathrm{A}: \mathrm{T}$ transverions is common among the aerobic revertants but rare among the anaerobic revertants. For trpA46, full revertants result from $A: T \rightarrow G: C$ or $A: T \rightarrow C: G$ base-pair substitutions. The proportion of full revertants for trpA46 is higher in the anaerobic than in the aerobic environment. Partial revertants (II PR) of trpA46 result from $\mathrm{A}: \mathrm{T} \longrightarrow \mathrm{T}: \mathrm{A}$ transversions. This class was not found within the anaerobic spectrum, whereas it was present, although rare, among the aerobic revertants. Class III of partial revertants (PR III) of trpA46 result from A:T $\rightarrow$ G:C transitions. This class occurred proportionally in the presence and absence of oxygen. 


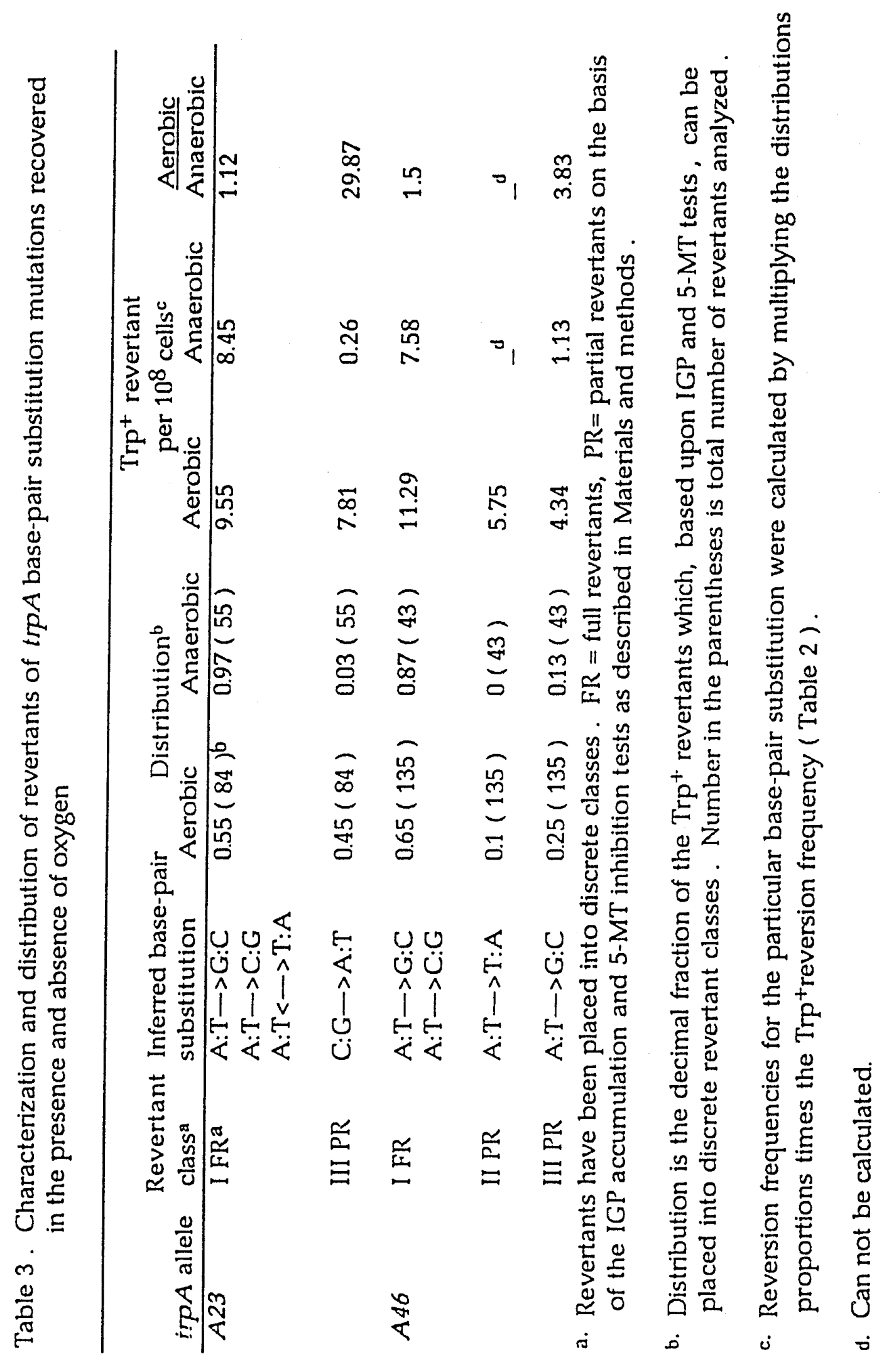




\section{Discussion}

We have attempted to provide a consistently stable anaerobic environment over a 5-day incubation period at $37^{\circ} \mathrm{C}$ in which to measure mutation and reversion frequencies. A constant flow of non-oxygen gases has been used by previous experimenters to achieve long-term "anaerobiosis" (Bruyninckx et al., 1978; Hartman et al., 1984) but significant quantities of oxygen $(0.1 \%)$ were present in such experiments. In addition, prereduced and anaerobically sterilized (PRAS) media were used in our experiments whereas previous studies (Hartman et al., 1984) have only used aerated degassed media. Such media are made on the laboratory bench and then used in the anaerobic environment.

We have determined forward mutation frequencies to nalidixic acid and rifampicin resistance along with $\operatorname{Trp}^{+}$reversion frequencies using E. coli trpA strains. The $\operatorname{trp} A$ system also allows the direct detection of particular transition and transversion mutations since amino acid substitutions are known at several sites and the entire $\operatorname{trp} A$ gene has been sequenced (Nichols and Yanofsky, 1979). We found that spontaneous mutation frequencies were generally reduced about 2-3-fold for $\mathrm{Nal} R$ and $\mathrm{Rif} R$ when the oxygen level changed from $20 \%$ (air) to $\sim 0 \%$. This suggests that the absence of oxygen is responsible for a $50-70 \%$ reduction in spontaneous base-pair substitution mutagenesis. This compares to a $32 \%$ reduction found in a wild type strain of S. typhimurium (Stroz et al., 1987).

Independent sample $\mathrm{T}$-tests for $\mathrm{Nal} R$ and $\mathrm{Rif} R$ frequencies were done in order to determine whether aerobic and anaerobic mutation frequencies were significantly different. No significant differences between means were 
found. There is insufficient evidence to conclude that the means of the two populations are the same. Failure to detect a significant difference may relate to the sample sizes which were not large and extremely variable.

The $\operatorname{Trp}^{+}$reversion frequencies generally revealed a 2-3-fold reduction under anaerobic conditions, although the $\operatorname{trp} A 58$ strain produced no revertants in the absence of oxygen. Much of the large variability in $\operatorname{Trp}^{+}$ reversion frequencies was due to large differences in total cell titers. A second method for obtaining reversion frequencies, $\operatorname{Trp}^{+}$colony per plate counts, was used to decrease the variability between replicas.

In general the titer of total cells grown anaerobically was lower as compared with aerobic conditions. This indicates possible differences in the rate and mechanisms of carbon, energy and electron flow and their roles in the adaption between aerobic and anaerobic metabolism (Gary et al., 1967; Krebs, 1972).

A cautious interpretation of the data is demanded in these preliminary experiments. Some $\mathrm{Nal}^{R}$ and $\mathrm{Rif}^{\mathrm{R}}$ mutants and $\operatorname{Trp}^{+}$revertants may be unable to form colonies under anaerobic conditions. If this number is significant, an underestimation of anaerobic mutation and reversion frequencies is produced since mutants and revertants could not be scored. Since a large number of different mutational events give rise to $\mathrm{Nal} R$ and Rif $R$ mutations (Jin and Gross, 1988) and $\operatorname{Trp}^{+}$revertants (Yanofsky et al., 1966), the experiments needed to check the growth of each mutant and revertant type under anaerobic conditions becomes a difficult task. No Trp ${ }^{+}$ revertants were found for the $\operatorname{trp} A 58$ allele in the anaerobic environment. However, the vast majority of aerobic spontaneous revertants for $\operatorname{trp} A 58$ are 
slow-growing suppressed mutants (Yanofsky et al., 1966) and they be an example of revertants unable to form colonies on selective plates in the chamber.

Base-pair substitutions are the prominent class of spontaneous revertants in the $\operatorname{trp} A$ system. In the limited number of $\operatorname{trp} A$ sites used in this study, transversions appear to be more reduced in frequency than transitions in the anaerobic environment. Both A:T $\rightarrow$ T:A (II PR, trpA46) and $\mathrm{C}: \mathrm{G} \rightarrow \mathrm{A}: \mathrm{T}(\mathrm{III} \mathrm{PR}, \operatorname{trp} A 23$ ) transversions are infrequent or absent in the anaerobic $\operatorname{Trp}^{+}$spectrum (Table 3 ). No $\operatorname{Trp}^{+}$revertants for $\operatorname{trp} A 58$ were recovered under anaerobic conditions (Table 2). As mentioned previously most aerobic spontaneous revertants of $\operatorname{trp} A 58$ are actually suppressed mutants (Yanofsky et al., 1966) with the suppressors being caused by G:C $\rightarrow$ A:T transition mutations occurring at a t-RNA gene site (Squires and Carbon, 1971). Failure to detect these mutations anaerobically may mean that the causative G:C $\rightarrow$ A:T transitions at suppressor sites are reduced or eliminated by the anaerobic environment or that suppressed colonies are not formed anaerobically although the mutational event does occur. Hartman et al., (1984) found an increase in G:C $\rightarrow$ A:T transitions produced with the hisG46 allele of $S$. typhimurium under anaerobic conditions. However, these were intragenic reversion events while the target for $\mathrm{G}: \mathrm{C} \rightarrow \mathrm{A}: \mathrm{T}$ substitutions in this study is a t-RNA gene so the two situations are not directly comparable.

In contrast to the results of Hartman et al. (1984), Mortelmans and Cox (1992) found no His ${ }^{+}$revertants of hisG46 in S. typhmrium under the strict anaerobic environment of an anaerobic chamber using prereduced media. 
The absence of $\mathrm{His}^{+}$revertant colonies was attributed to the possible production of a secreted inhibitor of prototrophic cells by stationary phase cells. In the experiments in this study mutational events were mainly occurring during exponential growth before the cultures reached stationary phase. The experiments were done completely within the anaerobic chamber and using prereduced media except for the centrifugations needed to the wash cells after growth but before plating.

The role of oxygen in the production of spontaneous mutations remains to be clarified. Reduction of molecular oxygen of one, two, or three electrons leads to the formation of the superoxide radicals $\left(\mathrm{O}_{2}^{-}\right)$, hydrogen peroxide $\left(\mathrm{H}_{2} \mathrm{O}_{2}\right)$, and the hydroxyl radicals $\left(\mathrm{HO}^{\circ}\right)$, respectively (Fridovich, 1978). The mutagenic pathway for $\mathrm{H}_{2} \mathrm{O}_{2}$ has been studied in great detail (Carlsson et al., 1988; Imlay and Linn, 1988). At low $\mathrm{H}_{2} \mathrm{O}_{2}$ concentrations mutagenicity is correlated with SOS induction (Imlay and Linn, 1988), while at higher concentrations the correlation is weaker. While exogenously added $\mathrm{H}_{2} \mathrm{O}_{2}$ is clearly mutagenic in $E$. coli the possible mutagenic effect of $\mathrm{H}_{2} \mathrm{O}_{2}$ endogenously produced via aerobic respiration has not been resolved.

It has been shown that a number of proteins are induced by $\mathrm{H}_{2} \mathrm{O}_{2}$ and constitute a system regulated by the oxyR locus in E. coli and S. typhimurium (Christman et al., 1985, 1989; Tao et al., 1989). One of the genes regulated as part of the $\operatorname{axy} R$ regulon is $k a t G$, the structural gene for the HPI catalase which removes $\mathrm{H}_{2} \mathrm{O}_{2}$ by converting it to $\mathrm{H}_{2} \mathrm{O}$ and $\mathrm{O}_{2}$ (Loewen et al., 1985).

E. coli has a second catalase, HPII, encoded by the kat $E$ gene which is not a part of the oxyR regulon (Loewen and Triggs, 1984; Loewen et al., 1985). An E. coli strain lacking both HPI and HPII catalase activities showed only about a two- 
fold increase in spontaneous mutation frequencies under aerobic conditions (Abril and Pueyo, 1990) suggesting that $\mathrm{H}_{2} \mathrm{O}_{2}$ may be a very weak endogenenous mutagen or other cellular mechanisms are available to deal with $\mathrm{H}_{2} \mathrm{O}_{2}$ or the damage it causes in wild type strains.

$E$. coli cells are also equipped with two superoxide dismutases encoded by the $\operatorname{sod} A$ and $\operatorname{sod} B$ genes (Farr and Kogoma, 1991). Superoxide dismutases catalyze the conversion of $\mathrm{O}_{2}^{-}$to $\mathrm{H}_{2} \mathrm{O}_{2}$. The sodA gene is $\mathrm{O}_{2}{ }^{-}$induced as part of the soxR regulon (Kogoma et al., 1988). A sodA sodB double mutant was found to have spontaneous aerobic mutation frequencies to Rif $R$, the same mutational event scored in this study, about 40 -fold higher than wild type frequencies (Farr et al., 1986; Touati and Far, 1990). The sodA single mutant showed a 9-fold increase over wild type while the sodB single mutant showed no increase. Therefore it is possible that some aerobic spontaneous mutagenesis may result from $\mathrm{O}_{2}^{-}$damage to DNA.

In addition to differences in the induction of enzyme systems to directly prevent or repair DNA damage caused by free radicals, aerobic and anaerobic environments lead to multiple changes in gene expression at other loci that may impact on the production of spontaneous mutations without the need of direct DNA damage (Smith and Neidhardt, 1983; Choe and Rezinkoff, 1991). Facultative anaerobes such as E. coli obtain energy from respiration or fermentation with the chosen mode dependent upon the availability of oxygen or alternate electron acceptors and the fermentability of the carbon source. Two networks of oxygen regulated gene expression have recently been reported (Spiro and Guest, 1991). The ArcA system includes the ArcA protein which can act as an anaerobic repressor to turn off several 
aerobically functioning genes such as those encoding cytochrome o oxidase, the terminal oxidase of aerobic growth. As an anaerobic activator ArcA turns on cytochrome d oxidase expression which replaces cytochrome o oxidase when oxygen becomes limiting.

The Fnr system is also involved in the anaerobic repression or activation of numerous gene activities (Spiro and Guest, 1991). These include the repression of both cytochrome $\mathrm{d}$ and $\mathrm{o}$ oxidase and activation of expression of gene products used during anaerobic respiration such as nitrate reductase and fumarate reductase (Bonnefoy et al., 1988; Jones et al., 1987).

Overall it has been estimated by two-dimensional protein gel analysis that over $125 \mathrm{E}$. coli proteins are influenced by the choice between aerobic and anaerobic environments (Sawers et al., 1988; Smith and Neidhardt, 1983). What role, if any, that each of these proteins has in the production of aerobic and anaerobic spontaneous mutations remains to be clarified. 


\section{Literature cited}

Abril, N. and C. Pueyo (1990). Mutagenesis in Escherichia coli lacking catalase. Environ. Mol. Mutagen, 15, 184-189.

Adelman, R., R. L. Saul, and B. N. Ames (1989). Oxidative damage to DNA: relation to species metabolic rate and life span. Proc. Natl. Acad. Sci. (U.S.A.), 85, 2706-2708.

Allen, M. K. and C. Yanofsky (1963). A biochemical and genetic study of reversion with the A-gene A-protein system of Escherichia coli tryptophan synthetase. Genetics, 48, 1065-1083.

Ames, B. N., (1982). Carcinogens and anti-carcinogens. In Sorsa M, Vainio $\mathrm{H}$ (ed.). Mutagens in our environment. Alan R. Liss, Inc., (New York) p. 11-26.

Ames, B. N. (1983). Dietary carcinogens and anti-carcinogens. Science, 221, 1256-1264.

Amstad, P., and P. Cerutti (1990). Genetic modulation of the cellular antioxidant defense capacity. Environ. Health Perspect., 88, 77-82.

Bennett, P. B., D. Paphadjopoulos and A. D. Bangham (1967). The effect of raised pressure of inert gases on phospholipid membranes. Life Sci, $6,2527-2533$.

Berg, C. C., R. A. Nilan, and G. F. Konzak (1965). The effect of pressure and seed water content on the mutagenic action of oxygen in barley seeds. Mutation Res., 2, 263-273

Bielski, B. H. J. (1985). Reactivity of $\mathrm{HO}_{2} / \mathrm{O}_{2}^{-}$radicals in aqueous solution. Phys. Chem. Ref. Data, 14, 1041-1045.

Bonnefoy, V., M. Fons, J. Ratouchniak, M. C. Pascal, and M. Chippaux (1988). Aerobic expression of the nar operon of Escherichia coli in a fnr mutant. Mol. Microl., 2, 419-425.

Breimer, L. H. (1990). Molecular mechanisms of oxygen radical and carcinogenesis and mutagenesis: the role of DNA base damage. Mol. Carcinogenesis, 3, 188-197. 
Bruyninckx, W. J. H. S. Mason and S. A. Morse (1978). Are physiological oxygen concentrations mutagenic? Nature, 274, 606-607.

Carlsson, J., E. H. Berglin, R. Claesson, M. B. Edlund, and S. Persson. (1988). Catalase inhibition by sulfide and hydrogen peroxide-induced mutagenicity in Salmonella typhimurium strain TA 102. Mutation Res., 202, 59-64.

Cerutti, P. (1985). Prooxidants states and tumor promotion. Sci., 227, 375381.

Choe, M. and W. S. Rezniokoff (1991). Anaerobically expressed Escherichia coli genes identified by operon fusion techniques. J. Bacteriol., 173, 6139-6146.

Christman, M. F., R. W. Morgan, F. S. Jacoboson, and B. N. Ames (1985). Positive control of regulon for defenses against oxidative stress and some heat shock proteins in Salmonella typhimurium. Cell, 41, 753-762.

Christman, M. F., G. Storz, and B. N. Ames. (1989). OxyR, a positive regulator of hydrogen peroxidase-inducible genes in Escherichia coli and Salmonella typhimurium is homologus to a family of bacterial regulatory protein. Proc. Natl. Acad. Sci. (U.S.A.), 86, 3484-3488.

Conger, A. D., L. M. Fairchild (1952). Breakage of chromosomes by oxygen. Proc. Natl. Acad. Sci. (U.S.A.), 38, 289-299.

Cox, E. C., G. E. Degenen and M. L. Scheppe (1972). Mutator gene studies in Escherichia coli the mutS gene, Genetics, 72, 551-567.

Cox, M. E., and J. I. Mangels (1976). Improved chamber for the isolation of anaerobic microorganisms. J. Clin. Microbiol., 4, 40-45.

Cutler, R. G. (1984). Antioxidants, aging and longevity. In W. A. Pryor (ed ), Free radicals in biology, vol 6. Academic Press Inc., (New York) p. $371-428$.

Dowell, V. R. (1972). Comparison of techniques for isolation and identification of anaerobic bacteria. Am. J. Nutr., 25, 1343-1355. 
Farr, S. B. R. D. Ari, and D. Touati (1986). Oxygen-dependent mutagenesis in Escherichia coli lacking superoxide dismutase. Proc. Natl. Acad. Sci. (U.S.A.), 83, 8268-8272.

Farr, S. B., and T. Kogoma (1991). Oxidative stress responses in Escherichia coli and Salmonella typhimurium. Microbiol. Rev., 55, 561-585.

Fenn, W. O., G. Gerschman, D. L. Gilbert, D. E. Terwilliger, and F. V. Cothran (1957). Mutagenic effects of high oxygen tensions on Escherichia coli. Proc. Natl. Acad. Sci. (U.S.A.), 43, 1027-1032.

Floyd, R. A. (1990). Role of oxygen free radicals in carcinogenesis and brain isochemia. FASEB J., 4, 2587-2597.

Foote, C. S. (1982). Light, oxygen and toxicity. In A. Autor(ed.), Pathology of oxygen. Academic Press Inc., (New York), p. 21-44.

Fowler, R. G., G. E. Degnen and E. C. Cox (1974). Mutational specificity of a conditional Escherichia coli mutator, mut D5 Mol. Gen. Genet., $133,179-191$.

Fridovich, I (1977). Oxygen is toxic. Bioscience, 27, 462-466.

Gifford, G. D. ( 1968 ). Mutation of an auxotrophic strain of Escherichia coli by high pressure oxygen. Biochem. Biophys. Res. Commun., 33, 294298.

Gray, C. T., J. W. T. Wimpenny, D. E. Hughes, and M. R. Mossman. (1967). Regulation of metabolism in facultative bacteria. I. Structural and functional changes in Escherichia coli associated with shifts between the aerobic and anaerobic states. Biochim. Biophys. Acta., 117, 22-32.

Halliwell, B (1987). Oxidants and human disease: some new concepts. FASEB J., 1, 358.

Halliwell, B and J. M. C. Gutteridge (1990). Role of free radicals and catalytic metal ions in human disease: an overview. Methods Enzymol., 186, 1-85

Harman, D. (1962). Role of free radicals in mutation, cancer, aging, and the maintenance of life Radiat. Res., 16, 753-763. 
Hartman, Z., P. E. Hartman, W. M. Barnes, and E. Tuley (1984). Spontaneous mutation frequencies in Salmonella: enhancement of $\mathrm{G} / \mathrm{C}$ to $\mathrm{A} / \mathrm{T}$ transitions and depression of deletion and frameshift mutation frequencies afforded by anoxic incubation. Environ. Mol. Mut., 6, 633-650.

Hill, O., and H. Allen (1978). The chemistry of dioxygen and its reduction products. In D. W. Fitzsimons (ed.), Oxygen free radicals and tissue damage. Elsevier Sciencse Publishing, Inc., (New York), p. 5-12.

Imaly, J. A. and S. Linn (1988). DNA damage and oxygen radical toxicity. Science, 240, 1302-1309.

Jin, D. J., and C. Gross, (1988). Mapping and sequencing of mutations in Escherichia coli rpoB gene that lead to rifampicin resistance. J. Mol. Biol., 202, 45-58.

Jones, H. M. and R. P. Gunsalus (1987). Regulation of Escherichia coli fumarate reductase ( frd $A B C D$ ) operon expression by respiratory electron acceptors and the finr gene product. J. Bacteriol., 169, 33403349.

Kelly, M., and J. M. Baden (1980). Oxygen mutagenicity. Mutation Res., 77, 185-188.

Kogma, T., S. B. Farr, K. M. Joyce, and D. O. Natvig (1988). Isolation of genes fusions (soi ::lacZ) inducible by oxidative stress in Escherichia coli. Proc. Natl. Acad. Sci. (U.S.A.), 85, 4799-4803.

Krebs, H. A. (1972). The Pasteur effect and the relations between respiration and fermentation. In P.N. Campbell and F. Dickens (eds ), Essays in biochemstry, vol 8. Academic Press, Inc., (New York), p.1-34.

Lester, G. and C. Yanofsky (1961). Influence of 3-methylanthranilic acids on the formation of tryptophane synthetase in Escherichia coli. J. Bacteriol., 81, 81-90.

Lin, E. C., and D. R. Kuritzkes (1987). Escherichia coli andSalmonella typhimurium cellular and molecular microbiology. In F. C. Neidhart (ed.), American Society for Microbiolgy, (New York), p. 201-221. 
Loewn, P. C, and B. L. Triggs (1984). Genetic mapping of kat $F$, a locus that with $k a t E$ affects the synthesis of a second catalase species in Escherichia coli. J. Bacteriol., 160, 668-675.

Loewn, P. C, and B. L. Triggs, C. S. George, and B. E. Hrabarchuk (1985) Genetic mapping of kat $G$, a locus that affects synthesis of the bifunctional catalase-peroxidase hyroperoxidase I in Escherichia coli . J. Bacteriol., 162, 661-667.

Mortelmans, K. and M. Cox (1992). Evidence that inhibitors are formed which may interfere with the growth of revertant colonies in the Ames Salmonella and E. coli tryptophan reverse mutation colonies assays when strickly anaerobic condition are used. Mol. Environ. Mutagen, 20, 44-52.

Nichols, B. P. and C. Yanofsky (1979). Nucleotide sequences of $\operatorname{trp} A$ of Salmonella typhmurium and Escherichia coli : an evolutionary comparison. Proc. Natl. Acad. Sci. (U.S.A.), 76, 5244-5248.

Poole, R. K., and W. J. Ingeldew (1987). Pathways of electrons of oxygen. In F. C. Neidhardt, J. L. Ingraham, K. B. Low, B. Magasanik, M. Schaechter, and H. E. Umbarger (ed.), Escherichia coli and Salmonella typhimurium cellular and molecular biology. American Society for Microbiology, (Washington D. C.) p. 170-200.

Pryor, W. A. (1982). Free radical biology: Xenobiotics, cancer and aging. Ann. NY. Acad. Sci., 393, 1-22.

Sava, D. (1982). Spontaneous mutation rates in continuous cultures: the effect of some environmental factors. Microbios., 33, 81-92.

Sawers, R. G., E. Zehelein, and A. Bock (1988). Two dimensional gel electrophoretic analysis of Escherichia coli proteins: Influence of various anaerobic growth conditions and far gene product on cellular protein composition. Arch. Microbiol., 149, 240-244.

Simic, M. G., D. S. Bergtold and L. R. Karam (1989). Generation of oxy radicals in biological systems. Mutation Res., 214, 3-12.

Smith, M. W., and F. C. Neidhardt (1983). Proteins induced by anaerobiosis in Escherichia coli . J. Bacteriol., 154, 336-343.

Spiro, S., and J. R. Guest (1991). Adaptive responses to oxygen limitation in Escherichia coli .TIBS, 16, 310-314. 
Squires, C., and J. Carbon. (1971). Normal and mutant glycine transfer RNAs. Nature (London) New Biol., 233, 274-277.

Storz, G., L. A. Tartaglia, and B. N. Ames (1990). Transcriptional regulator of oxidative stress-inducible genes: direct activation of oxidation. Science, 248, 189-194.

Storz, G., M. Christman, H. Sies, and B. N. Ames (1987). Spontaneous mutagenesis and oxidative damage to DNA in Salmonella typhimurium. Proc. Natl. Sci. (U.S.A.), 84, 8917-8921.

Sturrock, J. E., and J. F. Nunn (1978). Chromosomal damage and mutations after exposure of Chinese hamster cells to high concentrations of oxygen. Mutation Res., 57, 27-33.

Tao, K., K. Makino, S. Yonei, A. Nakata, and H. Shingawa (1989). Molecular cloning and nucleotide sequencing of oxy $R$, the positive regulator gene of a regulon for an adaptive response to oxidative stress in Escherichia coli: homologies between OxyR protein and a family of bacterial activator proteins. Mol. Gen. Genet., 218, 371-376.

Totter, J. R. (1980). Spontaneous cancer and its possible relationship to oxygen metabolism. Proc. Natl. Acad. Sci. (U.S.A.), 77, 1763-1767.

Touati, D., and S. B. Farr. (1990). Elevated mutagenesis in bacterial mutants lacking superoxide dismutase. Methods Enzymol., $186,646-651$.

Yanofsky, C., J. Ito, and V. Horn (1966). Amino acid replacements and the genetic code, Cold Spring Harbor Sym. Quant. Biol., 31, 151-162.

Yost, F. J., and I. Fridovich (1976). Superoxide and hydrogen peroxide in oxygen damage. Arch. Biochem. Biophys., 175, 514-159. 